$\xi=$

\title{
Diversity of medicinal plants in homegardens in Tanjung Julu village, North Sumatra, Indonesia
}

\author{
Marina Silalahi* \\ Department of Biology Education, Faculty of Education and Teacher Training, Universitas Kristen Indonesia, Cawang, 13510, Indonesia \\ *Corresponding author E-mail:marina_biouki@yahoo.com
}

\begin{abstract}
Background: The homegardens is a landscape which rich of plants diversity, so it have been used by human to supply of needs.

Objective: To documention the medicinal plants in homegardens by local communities in Tanjung Julu village.

Methods: the research conducted through ethnobotany approach. We interviwed to 30 informants and explored the 30 homegardens in Tanjung Julu village at August-December 2012.

Results: A total 63 the medicinal plants species belonging to 48 genera and 29 families is reported with ethnomedicinal uses to curing the 20 diseases.Those that is used mostly belong to Zingiberaceae (11 species), Rutaceae ( 8 species), Euphorbiaceae (6 species),and Asteraceae (5 species). The medicinal plants in homegardens are economic commodities (18 species), vegetable (11species), and ornamental (9 species).

Conclusions: The medicinal plants in homegardens by local communities in Tanjung Julu villages for subsistence of local households, significantly contribute to conservation of biodiversity.
\end{abstract}

Keywords: Medicinal plants; homegardens; Tanjung Julu; North Sumatra.

\section{Introduction}

The homegardens is a landscape which rich of plants diversity, so it have been used by human to supply of their needs. The plants in homegardens have been used as alimentary, ornament, and medicinal plants (Eichemberg et al. 2009; Esquivel and Hammer 1992; Wezel \& Bender 2003; Larios et al. 2013; Silalahi 2014; Silalahi et al. 2015), biodiversity conservation (Kehlenbeck and Maass 2004; Larios et al. 2013), reduction soil erosion (Kehlenbeck and Maass 2004), and income (Kusumaningtyas et al. 2006; Larios et al. 2013; Galhena et al. 2013; High \& Shackleton 2000; Wezel \& Bender 2002). Kusumaningtyas et al. (2006) stated that the plants in homegarden contribute to income up to $11 \%$. The medicinal plants, especially the aromatic herbs, are grown in homegardens, some of them are cultivated as field crops, either in sole cropping or in intercropping systems and rarely asplantation crops (Padua et al. 1999).

The wealth of these homegardens related to the rural origin and to the culture of the owners (Kusumaningtyas et al. 2006; Eichemberg et al. 2010), socioeconomic, and the age group of familiar cycle (Lamont et al. 1999; Larios et al. 2013 ). The medicinal plants are the mostly of the plants in the homegardens after ornamental and edible plants (Larios et al. 2013; Galhena et al. 2013; Vila Ruiz et al. 2014). A total 93 species of medicinal plants are founded in homegardens of Rio Claro (Eichemberg et al. 2009), and 50 spesies in Tehuacan valley (Larios et al. 2013). The diversity of species in tropical homegardens to be very high due to species having different of life forms, height and canopy structure (Soemarwoto \& Conway1991).

Homegardens is one of the strongholds of diversity for food security, medicinal plants, and biodiversity conservation in the future. In fact, the importance of homegardens as foci of biodiversity conservation will have to intensify in the years ahead (Eichemberg et al. 2009). Those indicated of the importance research of the plants diversity in homegardens. Research of plants diversity in homegardens especially in the developing countries have been done widely reported, but few in Indonesia. The research of plants diversity in Indonesia homegardens done in Javanese (by Kusumaningtyas et al. 2006) and local communities Lampung (Kehlenbeck and Maass (2004). The mostly of them focused on ornamental and edible plant, but foci in medicinal plants is poor.

The increasing prevalence of degenerative diseases in the world and Indonesia, so that looking for to alternative treatments through uses of the medicinal plants. By local communities, the medicinal plants derived from homegardens, gardens, forest, yards, and agroforest (Silalahi et al 2014; Silalahi et al. 2015). Utilization of the homegardens as a sources of medicinal plants has advantages such as: additional income (High \& Shackleton, 2000; Wezel \& Bender, 2002) and easily to accessible (Silalahi et al 2015a), so that more than $50 \%$ of the medicinal plants are used as medicine founded in the homegarden (Amenu 2007).

Utilization of the medicinal plants by local communities related to the diversity cultural, ethnic, and biodiversity of sourounding enviroment. Indonesia has more than 300 ethnic, one of them is Batak ethnic ethnic. Batak ethnic group consists of five subethnic, which is one of sub-ethnic is Batak Angkola-Mandailing with regional distribution center in Mandailing-Natal (Bangun 2010). Homegardens by the Batak ethnic function as subsystem (Kusnick, 2006) and source of medicinal plants (Silalahi, 2014). The study of medicinal plants diversity in homegardens Tanjung Julu village conducted to documentation of local knowledge to uses of the medicinal uses as initial steps for its conservation. 


\section{Materials and methods}

\subsection{Study area}

This research conducted in the Tanjung Julu village, District Mandailing Natal, North Sumatra. The total area of those villages is 850 hectares, within the altitude of $250-800 \mathrm{~m}$ above sea level Tanjung Julu located at N 00'46'79'” and E 99'39'62'” (Figure 1).

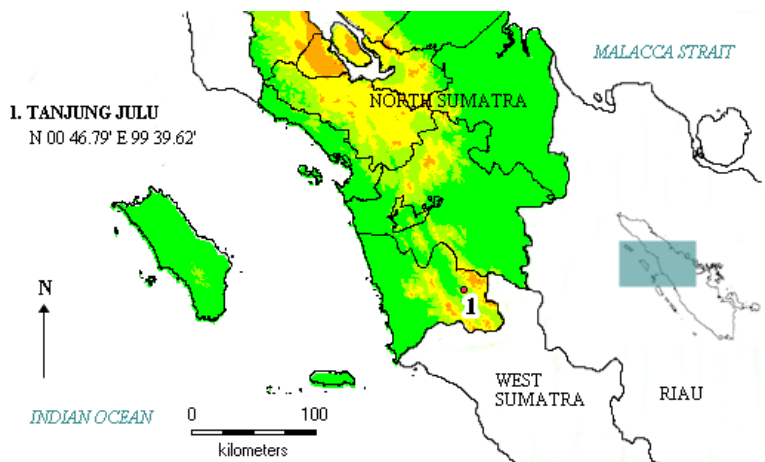

Fig. 1: Study Area in the Tanjung Julu Village, District Mandailing-Natal, North Sumatra.

\subsection{Data colection}

A total the 30 homegardens were studied and 30 people owners of homegardens were interviwed (modification of High \& Sheckleton, 2000). Semi-structured interviews were conducted to the owners of each homegardens sample, including: local name, part of uses, uses, and how to preparation. Interviews were conducted with ethnobotanical approach (Martin 1995; Alexiades 1996). We calculated the total of the medicinal plants obtained per homegardens and homegarden size through surveys. The voucher specimens of each medicinal plants were prepared and identified in the Herbarium Bogorience, Lembaga Ilmu Pengetahuan Indonesia (LIPI) Cibinong, Indonesia. Voucher specimens were deposited in the Herbarium of Universitas Indonesia. Data were analyzed using qualitative and quantitative methods. Qualitative analysis was done by grouping plants based upon usage category.

\section{Result}

A homegardens is a clearly bounded piece of land cultivated with a diverse mixture of annual and perennial crops, and on which a house is built. Size of homegardens in the Tanjung Julu village varies depend to owners $\left(100-300 \mathrm{~m}^{2}\right)$. The homegardens boundered by varies of plants. The most of plants in homegardens by local communities heve been used as edible, ornament, ritual medicinal plants, and the other uses. A total 61 species belonging 47 genera and 28 families of the medicinal plants were recorded in homegarden in Tanjung Julu village (Table 1). The each of homegardens founded 8-15 species of medicinal plants.

Zingiberaceae, Rutaceae, Euphorbiaceae, and Asteraceae are the most number of species with the number 11, 8, 6, and 5, respectively (Figure 2). Apiaceae, Lamiaceae, Rubiaceae, and Solanaceae have two species as medicine, while the other families have one species (Table 1).

The medicinal plants (63 species) in the homegardens of Tanjung Julu village uses to cure as many as 20 kinds of diseases. The number species of medicinal plants are used to cure each of the disease varies (Figure 2). The disease are fever, cough, diarrhea, gastroinstetinal disolder, itchy, injury, rasa, and marsidudu (Table $1)$.

The concept of disease by local communities are similar to the other local communities in North Sumatra. Rasa and marsidudu are diseases which spesific by local communities in Tanjung Julu village. Tuberculosis by local communities is called rasa. The patients of rasa arecharacterized by thin body, pale face, cough, andhard to breath. To curing those disease have been used of the medicinal plant which extracte from primer forest plus varies of Rutaceae (Citrus spp.) dan Zingiberaceae (Curcuma spp.). Marsidudu is traditional steam bath by llocal communities to cure mother postpartum.

Table1:The Medicinal Plants in The Homegardens of Tanjung Julu Village, District Mandailing-Natal, North Sumatra

\begin{tabular}{|c|c|c|c|c|c|}
\hline Family and Scientific name & Local names & Parf of uses & Uses & $\begin{array}{l}\text { Medicinal } \\
\text { Preparation(s) }\end{array}$ & $\begin{array}{l}\text { Cultivated; } \\
\text { Ruderal; Wild }\end{array}$ \\
\hline $\begin{array}{l}\text { Acanthaceae } \\
\text { Justicia gendarussa Burm.f. } \\
\text { Amaranthaceae }\end{array}$ & Sipilit & Leaves & Fever & Infusion & Wild \\
\hline $\begin{array}{l}\text { Celosia cristata L. } \\
\text { Amaryllidaceae }\end{array}$ & Rudang & Leaves & Fever, Cough & Infusion & Wild \\
\hline Crinum asiaticum L. & Ompu-ompu & $\begin{array}{l}\text { Bulbus, } \\
\text { Leaves }\end{array}$ & Fractures & Decoction; massage & Wild \\
\hline \multicolumn{6}{|l|}{ Annonaceae } \\
\hline Annona muricata L. & $\begin{array}{l}\text { Sibodak } \\
\text { Bulanda }\end{array}$ & Leaves, bark & $\begin{array}{l}\text { Gastrointestinal disolder, } \\
\text { Headache, Hypertention }\end{array}$ & Orally & Cultivated \\
\hline \multicolumn{6}{|l|}{ Apiaceae } \\
\hline Centella asiatica (L.) Urb. & Paga-paga & Leaves & Fever, Injury & Infusion;massage & Wild \\
\hline $\begin{array}{l}\text { Apium graveolens L. } \\
\text { Araceae }\end{array}$ & Seledri & Leaves & Hypertention & Orally & Cultivated \\
\hline Acorus calamus L. & Salin batu & Rhizomes & $\begin{array}{l}\text { Fever, Tuberculosis, Give birth, } \\
\text { Malnutrition, Headache }\end{array}$ & Orally; Decoction; & Cultivated \\
\hline \multicolumn{6}{|l|}{ Arecaceae } \\
\hline Areca catechu L. & pining & Roots & Tuberculosis & Orally & Ruderal \\
\hline $\begin{array}{l}\text { Cocos nucifera L. } \\
\text { Asteraceae }\end{array}$ & Harambir & Roots; fruits & Tuberculosis & Orally & Cultivated \\
\hline Ageratum conyzoides (L.) L & Siangur & Leaves & Injury, Diarrhea, Ulcer & Pilis; orally & Wild \\
\hline Blumea balsamifera (L.) DC. & Galunggung & Leaves & Injury, Diarrhea, Fever & Pilis ; orally & Cultivated \\
\hline Clibadium surinamense L. & Flowers jopan & Leaves & Injury, Diarrhea, Malaria & Pilis; orally & Wild \\
\hline $\begin{array}{l}\text { Mikania cordata (Burm.f.) } \\
\text { B.L.Rob. }\end{array}$ & Sirampas para & Leaves & Injury, Diarrhea, Malaria & Pilis; orally & Wild \\
\hline $\begin{array}{l}\text { Tithonia diversifolia (Hemsl.) } \\
\text { A.Gray }\end{array}$ & Bunga paet & Leaves & Injury, Diarrhea, Malaria & Pilis ; orally & Wild \\
\hline Bromeliaceae & & & & & \\
\hline $\begin{array}{l}\text { Ananas comosus (L.) Merr. } \\
\text { Campanulaceae }\end{array}$ & Honas & Fruits & Abortion & Orally & Cultivated \\
\hline Isotoma longiflora (L.) C.Presl & Leaves katarak & $\begin{array}{l}\text { Flowers; } \\
\text { leaves }\end{array}$ & Eye infection & Drops & Wild \\
\hline
\end{tabular}




\section{Caricaceae}

Carica papaya L.

Convolvulaceae

Ipomoea batatas L. (Lam.)

Crassulaceae

Kalanchoe pinnata (Lam.) Pers.

Euphorbiaceae

Euphorbia antiquorum L.

Manihot utilissima Pohl.

Phyllanthus niruri L.

Stachytarpheta mutabilis (Jacq.)

Vahl

Ricinus communisL.

Sauropus androgynus (L.) Merr.

Lamiaceae

Ocimumamericanum L.

Orthosiphon stamineus Benth.

Lauraceae

Persea americana Mill.

Liliaceae

Allium cepa L.

Cordyline fructicosa (L.) A.Chev.

Malvaceae

Hibiscus rosa-sinensis L.

Musaceae

Musa x paradisiaca L

Musa acuminata Colla

Myrtaceae

Psidium guajava $\mathrm{L}$

Oxalidaceae

Averrhoa carambola L.

Pandanaceae

Pandanus amaryllifolius Roxb.

Piperaceae

Piper betle L.

Piper attenuatum Buch.-Ham. Ex

Miq.

Punicaceae

Punica granatum L.

Rubiaceae

Morinda citrifolia L.

Cinchona ledgeriana (Howard)

Bern.Moens ex Trimen

Rutaceae

Citrus x aurantium L.

Citrus hystrix DC.

Citrus maxima (Burm.) Merr.

Citrus mitis Blanco

Citrus sp.1

Citrus sp.2

Citrus sp. 3

Citrus sp.4

Solanaceae

Capsicum annuum L.

Solanum torvum

Sapotaceae

Achras zapota L.

Zingiberaceae

Alpinia galangal L. (Willd.)

Boesenbergia pandurata (Roxb.)

Schltr.

Curcuma aeruginosa Roxb.

Curcuma domestica Valeton

Curcuma zanthorrhiza Roxb.

Curcuma zaedoria Roxb.

Etlingera eliator (Jack.) R.M.Sm.

Kaempferia galangal L.

Zingiber amaricans Blume

Zingiber officinale Roscoe

Zingiber purpureum Roscoe
Botik

Leaves

Diarrhea, Fever, Malaria

Gastrointestinal disolder

Ulcer, Fever

Tootache

Injury

Kidney disease

Chickenpox, Fever

Fever

Lactation

Marsidudu

Hypertention

Gastrointestinal disolder

Pokat

Leaves

Bawang

Merah

Silinjuang

Bunga raya

Pisang

Pisang

Jamborsik

Balimbing

Pandan

Simanat

Simanat

Delima

Mengkudu

Kina

Utte bunga

Utte pangir

Utte godang

Utte kasturi

Utte

albung/begu

Utte kejaren

Utte rihit

Utte susu

Lasiak cina

Rimbang

Sawo

Alas

Tomu kunci

Tomu itom

Nagorsing

Tomulawak

Hunik

tindosan

Sihala dairi

Hasihor

Lampuyang

Pege

Bunglei
Bulbus

Leaves

Leaves

Buds

Buds

Leaves

Fruits

Leaves

Leaves

Leaves

Leaves

Fruits

Leaves

Leaves, Fruits

Leaves, Fruits

Leaves, Fruits

Leaves, Fruits

Leaves, Fruits

Leaves, Fruits

Leaves, Fruits

Leaves, Fruits

Leaves

Fruits

Sap

Leaves,

Rhizomes

Rhizomes

Rhizomes

Leaves,

Rhizomes

Rhizomes

Rhizomess

Stems,

Leaves

Rhizomes

Rhizomes

Leaves,

Rhizomes

Rhizomes
Fever, Injury, Diarrhea

Fever

Fever, Chickenpox

Fractures

Fractures

Diarrhea

Hypertention, Chickenpox

Marsidudu

Injury

Injury, Fractrures

Gastrointestinal disolder

Hypertention

Malaria

Cough, Marsidudu

Marsidudu, Tuberculosis

Marsidudu, Tuberculosis

Marsidudu, Tuberculosis

Marsidudu, Tuberculosis

Marsidudu, Tuberculosis

Marsidudu, Tuberculosis

Marsidudu, Tuberculosis

Ulcer, Tootache

Hypertention

Diarrhea

Marsidudu, Itch

Marsidudu

Marsidudu, Tuberculosis

Diarrhea, Marsidudu

Gastrointestinal disolder,

Diarrhea

Tuberculosis, Cough

Marsidudu, Fever

Marsidudu, Cough

Marsidudu, Diarrhea

Marsidudu, Injury

Gastrointestinal disolder

Orally

Cultivated

Orally

Cultivated

Pilis

Wild

Drops

Pilis

Orally

Cultivated

Cultivated

Steam bath; pilis

Wild

pilis

Orally

Wild

Wild

Steam bath

Infusion

Infussion

Massage;

pilisdecoction; orally

Infusion

Ruderal

Cultivated

Wild

Cultivated

Infusion; bath

Cultivated

Wild

Cultivated

Massage

Massage

Cultivated

Wild

Orally

Cultivated

Orally; steam bath

Cultivated

Steam bath

Cultivated

Pilis

Pilis, massage

Ruderal

Orally

Wild

Cultivated

Orally

Cultivated

Orally

Cultivated

Orally; steam bath

Steam bath; infusion

Steam bath; infusion

Steam bath

Cultivated

Cultivated

Cultivated

Cultivated

Steam bath; infusion

Cultivated

Steam bath; infusion Cultivated

Steam bath; infusion Cultivated

Steam bath; infusion Cultivated

Pilis

Orally

Cultivated

Cultivated

Orally

Cultivated

Pilis; Steam bath

Cultivated

Steam bath;

Cultivated

Steam bath; infusion

Cultivated

Steam bath; infusion

Cultivated

Orally; decoction

Cultivated

Infusion

Cultivated

Steam bath; orally

Cultivated

Steam bath; orally

Steam bath; orally

Cultivated

Cultivated 


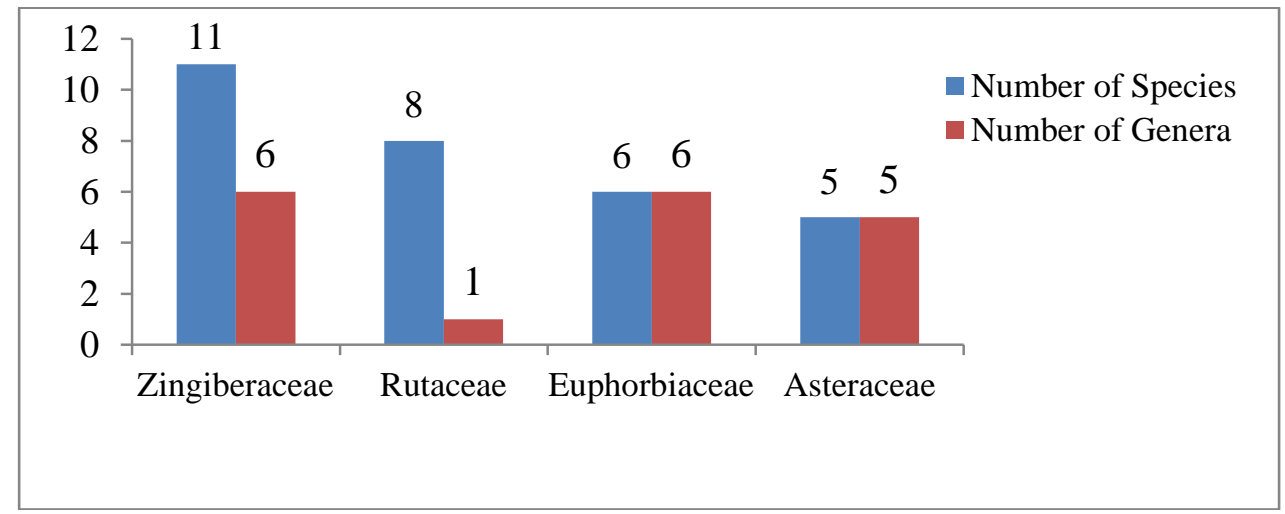

Fig. 2: Composition of Species and Family Used for Medicinal Plants in Homegarden Tanjung Julu Village.

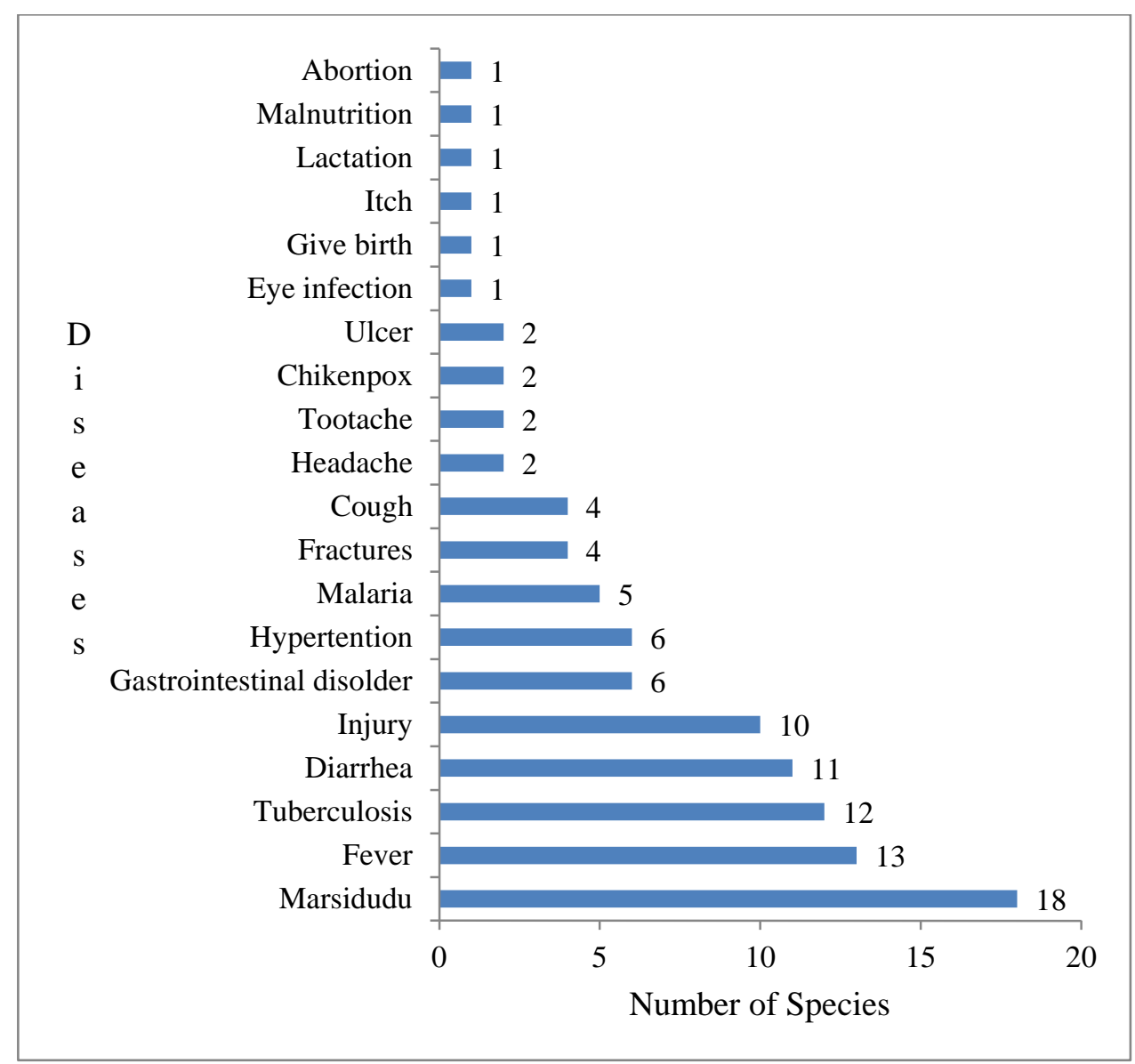

Fig. 3: Species Number to Cure of Diseases in Homegarden of Tanjung Julu, District Mandailing-Natal, North Sumatra.

\section{Discussion}

A total 63 species belonging to 48 genera and 29 families of the medicinal plants found in the homegardens of Tanjung Julu village. Those are more than in the homegardens Tambakreja (Pamungkas \& Judge, 2013), but less than in Catalonia (Agelet et al. 2000), Braszil (Eichemberg et al. 2013) and Techuan Valley (Larios et al. 2013). The differences of species number of medicinal plants in the homegardens are influenced by culture (Eichemberg et al. 2013; Vita Ruiz et al. 2014), the number of respondents (Eichemberg et al. 2013; Larios et al. 2013), size of homegardens (Galhena et al. 2013; Kehlenbeck and Maass 2004), and biodiversity in surrounding. The number of respondent and size of homegardens proportionel to the species number of the medicinal plant are found (Kehlenbeck and Maass 2004). The number of respondents surveyed are 350 people (Agelet et al. 2000), 23 people (Pamungkas and Judge 2013), whereas in this study are 30 people.
The medicinal plants were recorded in this study, the part similar to species are recorded by Pandey et al. (2006) in Andaman South i.e. coconut (Cocos nucifera), arecanut (Areca catechu), mango (Mangifera indica), banana (Musa paradisiaca), papaya (Carica papaya), and clove (Syzygium aromaticum), nutmeg (Myristica fragrans), and cinnamon (Cinnamomum burmannii). Those plants uses as fruits (banana, papaya, mango), and spices (coconut, nutmeg, clove). Eichemberg et al. (2010) states the homegardens studied were found to be complex units of production, with great plant richness composed of a mixture of native and exotic species. The total number of species of medicinal plants in the homegardens are influenced by the number of species are found in each homegarden. The number of species of medicinal plants in each in the homegardens of Tanjung Julu vilage are 5-8 spesies. Those number more than medicinal plants by High \& Shackleton (2000) are 3-5 spesies. Agelet et. al., (2000) stated the number of medicinal plants are found in the homegardens associated with the presence of non-cultivated plants in the homegardens, abundance in the wild, easily purchased on the market. The medicinal plants are found in homegardens in this study influenced by 
modernization that introduces of modern medicines with a cheap price, so people began to abandon the use of medicinal plants.

Rutaceae and Zingiberaceae is the cultivation of plants found in the homegardens. Those shows that various species of Rutaceae has a cultural value to local communities Angkola-Mandailing Batak. The homegardens owner cultivate of Citrus spp. in the yard or homegardens. The cultivation of the utte pangir (Citrus hystrix) in yard associated to mystically. The cultivation of Zingeberaceae (Curcuma spp.; Zingiber spp.) uses as spices and economy commodity and medicine. The plants in homegarden contributes to income the owner. The income of the local communities in South African sourced from plants in homegardens amount $269 \$$ per year (High \& Sheckleton, 2000), but in this study have not been calculated.

\section{Acknowledgements}

The Author would like to express our gratitude to the local communities Tanjung Julu, Mandailing-Natal District, North Sumatra, Indonesia for permission to this research and their help in the field.

\section{References}

[1] Agelet, A., M.A. Bonet, and J. Valles. (2000). Homegardens and Their Role as a Main Sources of Medicinal Plants in Mountain Region of Catalonia (Iberian Penisula). Economic Botany 54(3): 295-309.http://dx.doi.org/10.1007/BF02864783.

[2] Alexiades, M.N. (1996). Colecting Ethnobotanical Data: An Introduction To Basic Concepts And Techniques. In: Alexiades, M.N. 1996. Etnobotanical Research: A Field Manual. Scientific Publication Departemen the New York Botanical Garden, Bronx, New York: 53-96.

[3] Amenu, E. (2007). Use and Management of Medicinal Plants by Indegenous People of Ejaji Area (Chelya Woreda) West Shoa, Ethiopia: an Ethonobotanical Approach. [unpublished Tesis]. School of Graduate Studies, Addis Araba Universiti, Ethiopia.

[4] Eichemberg, M.T., M.C. de Mello Amorozo, and L.C. de Moura (2009). Species Composition and Plant Use in Old Urban Homegardens in Rio Claro, Southeast of Brazil.Acta Bot. Bras. 23(4): $\quad$ 1057-1075. $\quad$ http://dx.doi.org/10.1590/S010233062009000400016.

[5] Esquivel, M. and K. Hammer. (1992). The Cuban Homegarden 'Conuco': A perspective Environment For Evolution and In-Situ Conservation of Plant Genetic Resources. Genetic Resources and Crop Evolution 39: 9-22. http://dx.doi.org/10.1007/BF00052650.

[6] Bangun P. (2010). Bataks Culture. in: Koentjaraningrat. Man and Culture in Indonesia. Djambatan, Jakarta..

[7] Galhena, D.H., R. Freed, and K.M. Maredia. (2013). Home Gardens: A Promising Approach To Enhance Household Food Security And Wellbeing. Agriculture \& Food Security 2:8: 1-13. http://dx.doi.org/10.1186/2048-7010-2-8.

[8] de Padua, L.S., Bunyapraphatsara and R.H.M.J. Lemmens. (1999) Plants resources of South-East Asia no 12(1). Backhuys Publishers, Leiden: 21-70.

[9] High, C. and C.M Shackleton. (2000). The Comparative Value of Wild and Domestic Plant in Homegarden of a South African Rural Village. Agroforestry system 48: 141-156. http://dx.doi.org/10.1023/A:1006247614579.

[10] Kehlenbeck, K. and B.L. Maass. (2004). Crop Diversity and Classification of Homegardens in Central Sulawesi, Indonesia. Agroforestry Systems 63: 53-62. http://dx.doi.org/10.1023/B:AGFO.0000049433.95038.25.

[11] Kusumaningtyas, R., S. Kobayashi, and S. Takeda. (2006). Mixed Species Gardens in Java and The Transmigration Areas of Sumatra, Indonesia: A Comparison. Journal of Tropical Agriculture 44 (1-2): $15-22$.

[12] Kushnick, G.C. 2006.. Parent-offspring Conflick Among the Karo of North Sumatra. [unpublished Disertation]. Departement of Antrhropology University of Washington.

[13] Larios, C., A. Casas, M. Vallejo, A.I. Moreno-Calles, and J. Blancas. (2013). Plant Management and Biodiversity Conservation in Náhuatl homegardens of the Tehuacán Valley, Mexico. Journal of Ethnobiology and Ethnomedicine 9(74): 1-16. http://dx.doi.org/10.1186/1746-4269-9-74.
[14] Martin, G.J. (1995). Ethnobotany a people and plants conservation manual. Chapman and Hall. London, UK.

[15] Pamungkas, R.N. and L. Hakim. (2013). Ethnobotanical Investigation to Conserve Homegarden's Spices of Plants in Tambakrejo, Sumbermanjing Wetan, Southen of Malang. The Journal of Tropical Life Science 3(2): 96-103.

[16] Soemarwoto, O. and G.R. Conway. (1991). The Javanese home garden. Journal of Farming System Researchand Extention 2: 95118.

[17] Silalahi, M. 2014. The Ethnomedicine of The Medicinal Plants in Sub-ethnic Batak North Sumatra and The Conservation Perspective. [unpublished Disertation]. Program Studi Biologi, Program Pasca Sarjana, FMIPA, Universitas Indonesia.

[18] Silalahi, M., J. Supriatna, E.B. Walujo, and Nisyawati. (2015). Local knowledge of medicinal plants in sub-ethnic Batak Simalungun of North Sumatra, Indonesia. Biodiversitas. 16(1): 44 54. http://dx.doi.org/10.13057/biodiv/d160106.

[19] Vila-Ruiz, C.P., E. Meléndez-Ackerman, R. Santiago-Bartolomei, D. Garcia-Montiel, L. Lastra, C.E. Figuerola, and J. FumeroCaban. (2014). Plant Species Richness and Abundance In Residential Yards Across A Tropical Watershed: Implications For Urban Sustainability. Ecology and Society 19(3): 22: 1-11.

[20] Wezel, A. and S. Bender. (2002). Plant Species Diversity of Homegardens of Cuba and Its Significance for Household Food $\begin{array}{llll}\text { Supply. } & \text { Agroforestry } & \text { Systems } & \text { 57: }\end{array}$ http://dx.doi.org/10.1023/A:1022973912195. 